\title{
Characterization of a virus obtained from snakeheads Ophicephalus striatus with epizootic ulcerative syndrome (EUS) in the Philippines
}

\author{
Gilda D. Lio-Po ${ }^{1, *}$, Garth S. Traxler ${ }^{2}$, Lawrence J. Albright ${ }^{3}$, Eduardo M. Leaño ${ }^{1}$ \\ ${ }^{1}$ Aquaculture Department, Southeast Asian Fisheries Development Center, Tigbauan, Iloilo 5021, Philippines \\ ${ }^{2}$ Pacific Biological Station, Nanaimo, British Columbia, V9R 5K6, Canada \\ ${ }^{3}$ Department of Biological Sciences, Simon Fraser University, Burnaby, British Columbia, V5A 1S6, Canada
}

\begin{abstract}
This is the first report of the isolation and characterization of a fish virus from the Philippines. The virus was isolated using snakehead spleen cells (SHS) from severely lesioned epizootic ulcerative syndrome (EUS)-affected snakehead Ophicephalus striatus from Laguna de Bay, in January 1991. The virus induced cytopathic effects (CPE) in SHS cells yielding a titer of $3.02 \times 10^{6} \mathrm{TCID}_{50}$ $\mathrm{ml}^{-1}$ at $25^{\circ} \mathrm{C}$ within 2 to $3 \mathrm{~d}$. Other susceptible cell lines included bluegill fry (BF-2), catfish spleen (CFS) and channel catfish ovary (CCO) cells. Replication in chinook salmon embryo cells (CHSE-214) was minimal while Epithelioma papulosum cyprini cells (EPC) and rainbow trout gonad cells (RTG-2) were refractory. Temperatures of 15 to $25^{\circ} \mathrm{C}$ were optimum for virus replication but the virus did not replicate at $37^{\circ} \mathrm{C}$. The virus can be stored at -10 and $8^{\circ} \mathrm{C}$ for 30 and $10 \mathrm{~d}$, respectively, without significant loss of infectivity. Viral replication was logarithmic with a $2 \mathrm{~h}$ lag phase; viral assembly in the host cells occurred in $4 \mathrm{~h}$ and release of virus occurred $8 \mathrm{~h}$ after viral infection. A 1-log difference in $\mathrm{TCID}_{50}$ titer between the cell-free virus and the total virus was noted. Freezing and thawing the virus caused a half-log drop in titer. Viral exposure to chloroform or heating to $56^{\circ} \mathrm{C}$ for 30 min inactivated the virus. Exposure to pH 3 medium for 30 min resulted in a more than 100 -fold loss of viral infectivity. The 5-iododeoxyuridine (IUdR) did not affect virus replication, indicating a RNA genome. Neutralization tests using the Philippine virus, the ulcerative disease rhabdovirus (UDRV) and the infectious hematopoietic necrosis virus (IHNV) polyvalent antisera showed slight cross-reaction between the Philippine virus antiserum and UDRV but established no serological relationship with SHRV and IHN virus. Transmission electron microscopy (TEM) of SHS cells infected with the virus showed virus particles with typical bullet morphology and an estimated size of $65 \times 175 \mathrm{~nm}$. The Philippine virus was therefore a rhabdovirus, but the present study did not establish its role in the epizootiology of EUS.
\end{abstract}

KEY WORDS: Epizootic ulcerative syndrome (EUS) - Fish rhabdovirus - Characterization · Ophicephalus striatus $\cdot$ Snakehead $\cdot$ Disease $\cdot$ Cell susceptibility

Resale or republication not permitted without written consent of the publisher

\section{INTRODUCTION}

Epizootic ulcerative syndrome (EUS) is a malady among wild and cultured freshwater fishes in the Philippines and in many Asian countries. Lesions con-

*E-mail: liopo@aqd.seafdec.org.ph sist of severe ulcerative dermal necrosis with extensive erosion/sloughing of the underlying musculature and are often associated with a foul odor (Lio-Po et al. 1992). Fish species severely affected are snakeheads Ophicephalus striatus, catfish Clarias batrachus, gourami Trichogaster trichopterus and T. pectoralis, goby Glossogobius guirus, silvery theraponid Therapon plumbius, climbing perch Anabas testudineus, barbs Pun- 
tius spp., serpent fish Channa spp. and spiny eels Fluta alba (Tonguthai 1985). Outbreaks are more common between the months of September and March, which correlates with the time when lowest water temperatures occur.

Several species of bacteria and fungi have been found to be associated with EUS-affected snakeheads Ophicephalus striatus, but these have not been conclusively shown to be the primary disease agents of EUS (Lio-Po et al. 1992, 1996, 1998, Roberts et al. 1993, Callinan et al. 1995). Lilley \& Roberts (1997) reported the histological invasiveness of the EUS-associated Aphanomyces through the fish muscles after experimental exposure, but the development of gross EUSlike lesions was not mentioned. Conversely, rhabdoviruses and a birnavirus associated with EUS-lesioned fish have been isolated in Thailand (Frerichs et al. 1986, Hedrick et al. 1986, Kasornchandra et al. 1991), but their virulence has also not been established (Frerichs et al. 1993).

This study reports on the characteristics of a virus isolate, 91-97, isolated from an EUS-affected snakehead collected from Laguna de Bay, Philippines, in January 1991.

\section{MATERIALS AND METHODS}

Cell cultures. Atlantic salmon (AS), bluegill fry (BF-2) (Wolf \& Quimby 1966), channel catfish ovary (CCO) (Bowser \& Plumb 1980), chinook salmon embryo (CHSE-214), Epithelioma papulosum cyprini (EPC) (Fijan et al. 1983), rainbow trout gonad (RTG-2), catfish spleen (CFS) and snakehead spleen (SHS) (Lio-Po et al. 1999) cells were used. The CCO cells provided by RP Hedrick (University of California-Davis, USA) and the other cells provided by G.S.T. were maintained in minimum essential medium (MEM) with $10 \%$ fetal bovine serum (FBS) (MEM-10). SHS and CFS were maintained in Leibovitz medium (L15) supplemented with $10 \%$ FBS (L15-10).

Virus isolation. The test virus, 91-97, was isolated from several virus-positive filtrates obtained from severely lesioned EUS-affected snakeheads (mean weight $=175 \mathrm{~g}$ ) from Laguna de Bay, Philippines, in January 1991. External lesions and visceral organs (pool of spleen, liver, kidney and gills) were aseptically excised and transported in L15 medium containing $200 \mathrm{IU}$ penicillin $\mathrm{ml}^{-1}$ and $200 \mu \mathrm{g}$ streptomycin $\mathrm{ml}^{-1}$. Tissue homogenates were prepared, diluted to $10 \%$ (Chong et al. 1990) with Earle's balanced salt solution (EBSS) containing antibiotics and $50 \mu \mathrm{g}$ amphotericin $\mathrm{B} \mathrm{m} \mathrm{m}^{-1}$ (antibiotic-antimycotic mixture A). The homogenates were then centrifuged at $3000 \times g$ for $15 \mathrm{~min}$ at $4^{\circ} \mathrm{C}$. The supernatant was filtered through a $0.45 \mu \mathrm{m}$ pore size membrane filter (Millipore) and stored at $-70^{\circ} \mathrm{C}$ until virus assay.

Primary viral isolation was conducted in SHS cells in 24-well plates (Falcon) with L15 medium containing $4 \%$ FBS (L15-4) buffered with 1M N-2-hydroxyethylpiperazine- $\mathrm{N}^{\prime}$-2ethanesulfonic acid (Hepes). The plates were then incubated at $25^{\circ} \mathrm{C}$ for $7 \mathrm{~d}$. Blind passages were carried out on negative samples at least 3 times. Only isolates manifesting consistent cytopathic effects (CPE) in all subsequent passages were considered positive. The $\mathrm{pH}$ of all media used was adjusted to 7.2-7.4 with $7.5 \%$ sodium bicarbonate and supplemented with 100 IU penicillin G sodium, $100 \mu \mathrm{g}$ streptomycin sulfate, $25 \mu \mathrm{g}$ amphotericin $\mathrm{B} \mathrm{ml}^{-1}$ medium.

Other viruses. The snakehead rhabdovirus (SHRV) was provided by J. L. Fryer and J. Kasornchandra (Oregon State University, USA) while the infectious hematopoietic necrosis virus (IHNV) came from G.S.T. Ulcerative disease rhabdovirus (UDRV) was provided by G. N. Frerichs (Stirling University, UK).

Virus propagation and assay. The 91-97 viral isolate and the SHRV were propagated in SHS cells at $25^{\circ} \mathrm{C}$ for 2 to $5 \mathrm{~d}$ while IHNV was grown in CHSE-214 cells at $15^{\circ} \mathrm{C}$ for $2 \mathrm{wk}$. All viral titers were determined by the end-point dilution assay $\left(\mathrm{TCID}_{50}\right.$ ) of Rovozzo \& Burke (1973).

Susceptibility of cell lines. The susceptibility of different cell lines to the 91-97 virus isolate was tested using BF-2, CFS, CCO, EPC, and SHS at $25^{\circ} \mathrm{C}$ for $5 \mathrm{~d}$ and AS, CHSE-214, RTG- 2 at $20^{\circ} \mathrm{C}$ for $7 \mathrm{~d}$.

Virus replication at different incubation temperatures. Confluent SHS cells in $25 \mathrm{~cm}$ tissue culture flasks (Falcon) were inoculated at a multiplicity of infection (MOI) of 0.001 with the 91-97 virus. Seven inoculated flasks were incubated at each of the following temperatures: 15, 20, 25, 30 and $37^{\circ} \mathrm{C}$. Each day for $7 \mathrm{~d}, 1$ flask incubated at each test temperature was removed and the contents frozen at $-70^{\circ} \mathrm{C}$. After the experiment these fluids were rapidly thawed, clarified by low speed centrifugation, and the virus titer of each determined.

Virus stability at varying temperatures. Clarified viral suspensions were dispensed in $10 \mathrm{ml}$ aliquots in sterile tubes and stored at various temperatures: $-10,4$, 20 and $30^{\circ} \mathrm{C}$. After 3, 6, 10, 30, 60 and $120 \mathrm{~d}$, the virus titers were assayed.

Plaque assay. Plaque assay of the 91-97 virus was conducted in 8 well plates (Nunc) with SHS cells following the method of Burke \& Mulcahy (1980). At termination, the monolayers were overlaid with a formalin fixative-crystal violet stain solution and the plaques estimated as plaque forming units (pfu) $\mathrm{ml}^{-1}$.

Growth curve determination. The virus was inoculated at an MOI of 0.001 onto SHS cells grown in $25 \mathrm{~cm}$ flasks and incubated at $25^{\circ} \mathrm{C}$. At $2 \mathrm{~h}$ intervals for 
$24 \mathrm{~h}, 4$ flasks were removed and the titer of free and total virus assayed. Cell-free virus titer was determined from the supernatant pool of 2 flasks following low speed centrifugation. Total virus was determined from a pool of 2 flasks of both supernatant and homogenized cells after centrifugation. Both preparations were frozen at $-70^{\circ} \mathrm{C}$, then titered at the same time in 96-well plates at the end of the $24 \mathrm{~h}$ experiment.

Lipid solvent sensitivity. One ml clarified supernate containing the test virus was mixed with $0.5 \mathrm{ml}$ chloroform (reagent grade) or L15 medium alone according to the method of Feldman \& Wang (1961). After $10 \mathrm{~min}$ shaking at room temperature, the tubes were centrifuged at $1000 \times g$ for $10 \mathrm{~min}$ and the uppermost clear layer was removed for viral titration.

Sensitivity to 5-iododeoxyuridine (IUdR). Ten-fold serial dilution of the virus was inoculated on monolayers of SHS cells pretreated with $10^{-4} \mathrm{M}$ IUdR (Sigma) in EBSS or EBSS alone according to the method of Rovozzo \& Burke (1973). After 3 h incubation, the cells were washed and overlaid with L15-4 buffered with Hepes. The virus titers in both treatments were compared after $4 \mathrm{~d}$ incubation at $25^{\circ} \mathrm{C}$.

Effect of heat. Aliquots of the virus were heated in a water bath to $56^{\circ} \mathrm{C}$ (Rovozzo \& Burke 1973). After $0.5,1,2,4,6$ and $8 \mathrm{~h}$ incubation, the treated virus were each titered. Unheated virus inocula was used as control.

pH sensitivity. L15 medium adjusted to $\mathrm{pH} 3$ or $\mathrm{pH} 7$ was inoculated with the virus (Rovozzo \& Burke 1973). After $30 \mathrm{~min}$ incubation at $25^{\circ} \mathrm{C}$, the virus were titered. The $\mathrm{pH} 3$ treatment was neutralized with $0.1 \mathrm{~N} \mathrm{NaOH}$ before viral titration.

Stability to freeze-thaw. An aliquot of the virus was titered and frozen at $-70^{\circ} \mathrm{C}$. After each repeated freezing and thawing the virus titers were determined for up to 3 cycles according to Kasornchandra et al. (1991).

Purification of the virus. The virus was grown in SHS cells supplemented with $2 \%$ bovine serum albumin (BSA) (Sigma) (Wunner 1985) until complete destruction of the monolayer. After low speed centrifugation at $4^{\circ} \mathrm{C}$, the supernatant was purified by sucrose gradient ultracentrifugation (Engelking \& Leong 1989). The purified virus was resuspended in tris buffer and stored at $-70^{\circ} \mathrm{C}$.

Polyclonal antibody production. Approximately $100 \mu \mathrm{g}$ of purified viral protein was mixed with incomplete Freund's adjuvant and injected subcutaneously into a New Zealand white female rabbit. After $2 \mathrm{wk}$, the rabbit was boosted with 50 to $90 \mu \mathrm{g}$ of the antigen. Serum was collected after $2 \mathrm{wk}$, then stored in aliquots at $-70^{\circ} \mathrm{C}$. Normal rabbit serum was also collected before immunization as the negative control.

Neutralization test. Serological comparisons of the 91-97 virus with other warmwater fish rhabdoviruses associated with EUS (SHRV and UDRV) as well as IHNV were conducted by neutralization tests using polyclonal antisera raised against the 91-97 virus isolate, anti-IHNV from G.S.T. and anti-UDRV from G. N. Frerichs.

Serial 2-fold dilutions of each serum in Hanks' balanced salt solution (HBSS) were reacted with an equal volume of a $10^{4} \mathrm{TCID}_{50} \mathrm{ml}^{-1}$ of the 91-97 virus isolate for $1 \mathrm{~h}$ at $25^{\circ} \mathrm{C}$. Thereafter, neutralization titers were estimated in SHS cells incubated at $25^{\circ} \mathrm{C}$ for $5 \mathrm{~d}$ based on the method of Rovozzo \& Burke (1973). EPC cells were used for IHNV with MEM-4-hepes incubated at $15^{\circ} \mathrm{C}$ for $2 \mathrm{wk}$.

Electron microscopy. Snakehead spleen cells inoculated with the virus were fixed in $3 \%$ glutaraldehyde in Millonig's buffer and processed for resin blocking. The sections were stained with $1 \%$ (wt/vol) uranyl acetate and Reynold's lead citrate and viewed under the transmission electron microscope (TEM).

Experimental fishes. Cultured stocks of snakeheads are not available in the Philippines. Thus, healthy snakeheads, 40 to $80 \mathrm{~g}$, from a river source in Iloilo, Philippines were used. The fish were acclimated at ambient temperature $\left(27\right.$ to $\left.32^{\circ} \mathrm{C}\right)$ for $1 \mathrm{wk}$. Since EUS outbreaks have never occurred in Iloilo and 10 fish samples were confirmed virus-free and without neutralizing antibodies, the test fish were considered to be naïve. At least $3 \mathrm{~d}$ prior to the infection experiments, the naïve fish were maintained at 20 to $25^{\circ} \mathrm{C}$. Two fish were stocked per 51 aquarium, each aquarium containing UV-sterilized unchlorinated freshwater.

Infection experiments and reisolation of the test virus. Healthy, naïve snakeheads were exposed to the virus by bathing dermally-abraided test fish or unabraided fish, or by injection using intraperitoneal (IP), intrakidney (IK), intraspleen (IS) and intradermal (ID) routes of administration. In a second experiment, snakeheads fed and unfed for $2 \mathrm{wk}$ prior to the experiment were inoculated by intramuscular injection with the virus. In a third experiment, the test virus was tissue-passaged in healthy snakeheads 1 to 3 times before challenging naïve snakeheads by injection. Lesion development and mortalities were monitored daily for 2 wk. Lesion/muscle and visceral organ filtrates of experimental fish exposed to the virus were assayed for virus using SHS cells.

\section{RESULTS}

Infection of SHS cells with the virus induced CPE and yielded $3.02 \times 10^{6} \mathrm{TCID}_{50} \mathrm{ml}^{-1}$ at $25^{\circ} \mathrm{C}$ within 2 to 3 d. Similarly, virus titer by plaque assay in SHS cells

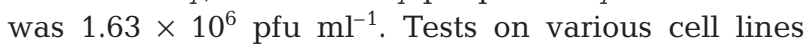
showed that BF-2, CFS, CCO and SHS cells were all 
susceptible to the 91-97 virus isolate, producing similar virus titers of $10^{6} \mathrm{TCID}_{50} \mathrm{ml}^{-1}$. The cytopathic effects consisted of granulation, rounding up and clumping, followed by detachment and lysis of cells (Fig. 1) among susceptible cell lines. Initial CPE was observed $24 \mathrm{~h}$ after viral inoculation, and there was complete destruction of the monolayer 2 to $3 \mathrm{~d}$ postviral exposure. In CHSE-214, the virus titer was approximately $1.35 \times 10^{3} \mathrm{TCID}_{50} \mathrm{ml}^{-1}$, but when blind passaged in SHS, a titer of $10^{7} \mathrm{TCID}_{50} \mathrm{ml}^{-1}$ was attained. EPC, AS and RTG-2 cells were refractory to the test virus.

Fig. 2 shows the 91-97 virus replication at various incubation temperatures. Virus titers of at least $10^{6} \mathrm{TCID}_{50} \mathrm{ml}^{-1}$ were achieved at 25 and $30^{\circ} \mathrm{C}$ on Day 1 and at 15 and $20^{\circ} \mathrm{C}$ on Day 2 with continuous high titers until Day 6 . At $15^{\circ} \mathrm{C}$, viral replication was initially slower but virus titers as high as $2.13 \times 10^{7} \mathrm{TCID}_{50} \mathrm{ml}^{-1}$ occurred on Days 4 to 7 . There was no replication of the virus at $37^{\circ} \mathrm{C}$.

Virus remained 'viable' for $30 \mathrm{~d}$ at $-10^{\circ} \mathrm{C}$. At $8^{\circ} \mathrm{C}$, the virus remained stable for $10 \mathrm{~d}$ while at 20 and at $30^{\circ} \mathrm{C}$, virus titer was drastically reduced after $3 \mathrm{~d}$ (Fig. 3).
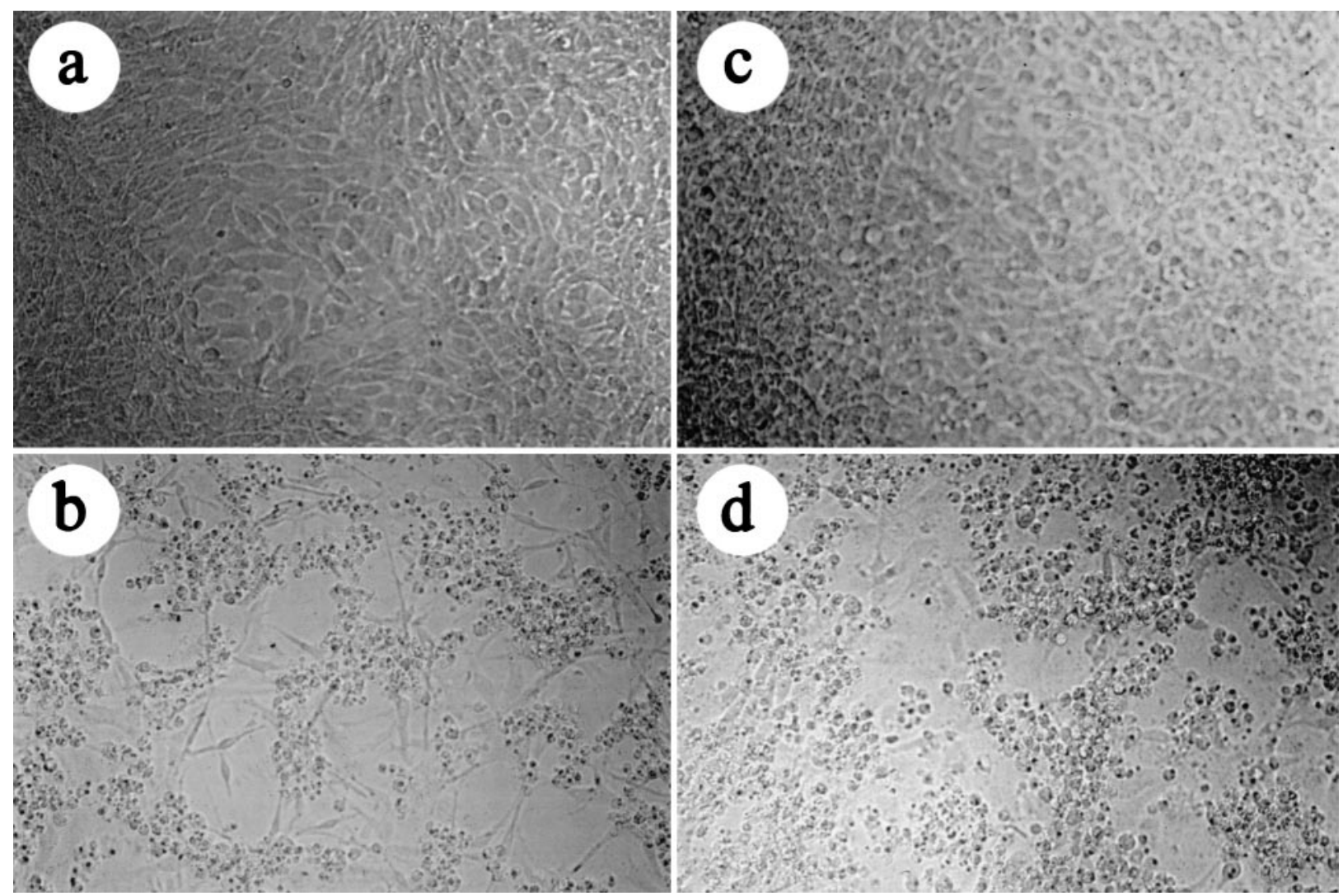

Assay of the cell-free virus (S) and the total virus (C) showed that viral replication followed a typical pattern. Viral replication demonstrated a lag phase of $2 \mathrm{~h}$ with evidence of initial virus assembly in the host cells as early as $4 \mathrm{~h}$ after viral exposure. Release of the replicated virus from the host cells was detectable $8 \mathrm{~h}$ after infection. A 1-log difference in $\mathrm{TCID}_{50}$ titer between the cell-free virus and the total virus was consistently observed thereafter until $12 \mathrm{~h}$, indicating continuous replication and subsequent viral release.

The freeze-thaw cycle caused an approximate half$\log$ drop in the titer of the 91-97 virus titer.

Table 1 summarizes the effect of several chemical and physical agents on the virus. Exposure to chloroform for $10 \mathrm{~min}$ or to heating to $56^{\circ} \mathrm{C}$ for $30 \mathrm{~min}$ inactivated the virus. Suspension at $\mathrm{pH} 3$ for 30 min caused a loss of viral infectivity of more than 2 orders of magnitude. IUdR did not affect replication of the virus, indicating that it had an RNA genome. All negative controls yielded normal viral titers.

Neutralization tests showed that anti-UDRV antiserum cross-reacted with the 91-97 virus isolate (Table 2), but both anti-91-97 and anti-UDRV antisera

Fig. 1. (a) Monolayer of catfish spleen cells (CFS) cultured in Leibovitz medium and (b) CFS cells showing cytopathic effects due to the $91-97$ virus isolate at $25^{\circ} \mathrm{C}_{i}$ (c) monolayer of snakehead spleen cells (SHS) cultured in Leibovitz medium and (d) SHS cells with cytopathic effects caused by the $91-97$ virus isolate at $25^{\circ} \mathrm{C}$ 


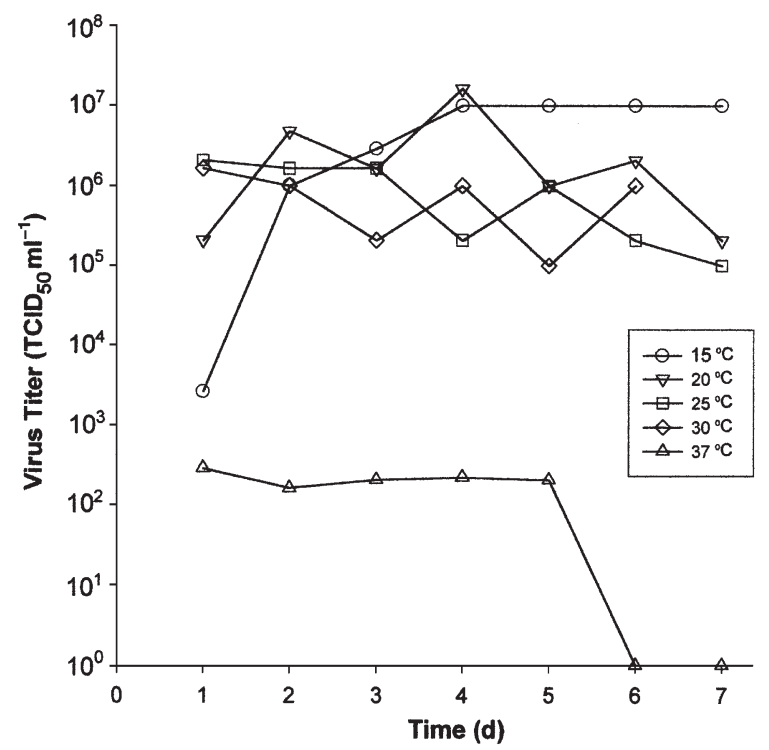

Fig. 2. Titers of the 91-97 virus isolate in snakehead spleen cells (SHS) following incubation in Leibovitz medium at different times (d) and temperatures $\left({ }^{\circ} \mathrm{C}\right)$

did not cross-react with SHRV. Anti-IHNV also did not react with the 91-97 virus isolate. The pre-immune serum of the rabbit from which the anti-91-97 virus was prepared yielded very high neutralization titers against UDRV that nullified the test for UDRV.

Fig. 4 illustrates the 91-97 virus isolate as viewed by TEM of SHS cells infected with the virus. The morphology of the virus is typical of a bullet-shaped rhabdovirus. The virus size is estimated as $65 \times 175 \mathrm{~nm}$.

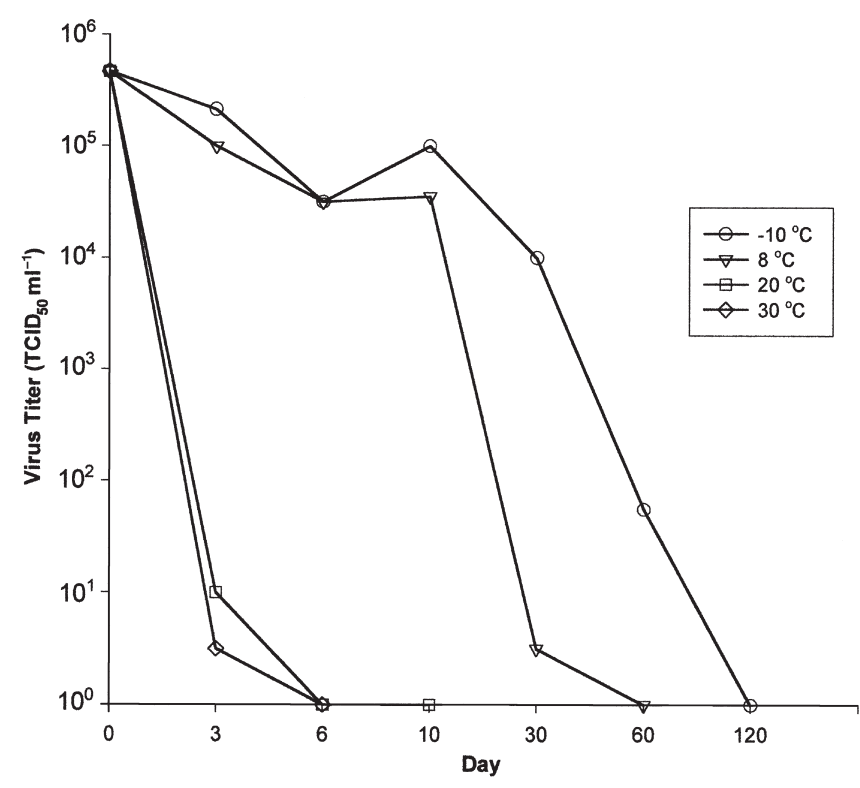

Fig. 3. Temporal stability of the 91-97 virus isolate at 4 temperatures $\left({ }^{\circ} \mathrm{C}\right)$
Table 1. Effect of several chemical agents and heat on the viability of the 91-97 virus isolated from EUS-affected snakehead Ophicephalus striatus and assayed in snakehead spleen cells at $25^{\circ} \mathrm{C}$. IUdR: 5-iododeoxyuridine; EBSS: Earle's balanced salt solution

\begin{tabular}{|lc|}
\hline Agent & Inactivation \\
\hline $1: 3$ Chloroform $(10 \mathrm{~min})$ & Yes \\
Control:Leibovitz medium & No \\
Heat at $56^{\circ} \mathrm{C}(30 \mathrm{~min})$ & Yes \\
Control: $25^{\circ} \mathrm{C}(30 \mathrm{~min})$ & No \\
$10^{-4} \mathrm{M} \mathrm{IUdR}(3 \mathrm{~h})$ & No \\
Control:EBSS & No \\
pH $3(30 \mathrm{~min})$ & Yes \\
pH $7(30 \mathrm{~min})$ & No \\
\hline
\end{tabular}

No viral pathology was induced following experimental challenges. Virus, however, was recovered from visceral organs until Day 8 post-challenge for fish infected by the IP route and until Day 5 post-challenge in fish infected by intramuscular injection. The virus was detected predominantly in the gonad and kidney.

\section{DISCUSSION}

This is the first record of a virus isolated from a diseased fish in the Philippines.

The virus was sensitive to heat at $56^{\circ} \mathrm{C}, \mathrm{pH} 3$, and chloroform, which indicated the presence of a lipidcontaining envelope. It was resistant to IUdR, a characteristic of viruses with RNA genomes. These attributes plus its typical bullet-shaped morphology identified it as a rhabdovirus.

The virus was propagated in a wide range of cells derived from fish species known to be susceptible to natural infections with viruses, such as CFS and SHS cells. Cells of BF-2 and CCO were also susceptible to

Table 2. Neutralization titers of 3 polyvalent antisera with the 91-97 virus isolate, UDRV, SHRV and IHNV. 91-97: virus isolated from EUS-lesioned snakehead in the Philippines; UDRV: ulcerative disease rhabdovirus; SHRV: snakehead rhabdovirus; IHNV: infectious hematopoietic necrosis virus; NT: not tested; ${ }^{*}$ Results disregarded the cross-neutralization titer obtained because high titer was detected in the preimmune serum

\begin{tabular}{|lccc|}
\hline Virus & $91-97$ virus & $\begin{array}{c}\text { Antisera } \\
\text { UDRV }\end{array}$ & IHNV \\
\hline $91-97$ & 91 & 25 & 0 \\
UDRV & $*$ & 645 & NT \\
SHRV & 0 & 0 & NT \\
IHNV & 6 & NT & 6085 \\
\hline
\end{tabular}




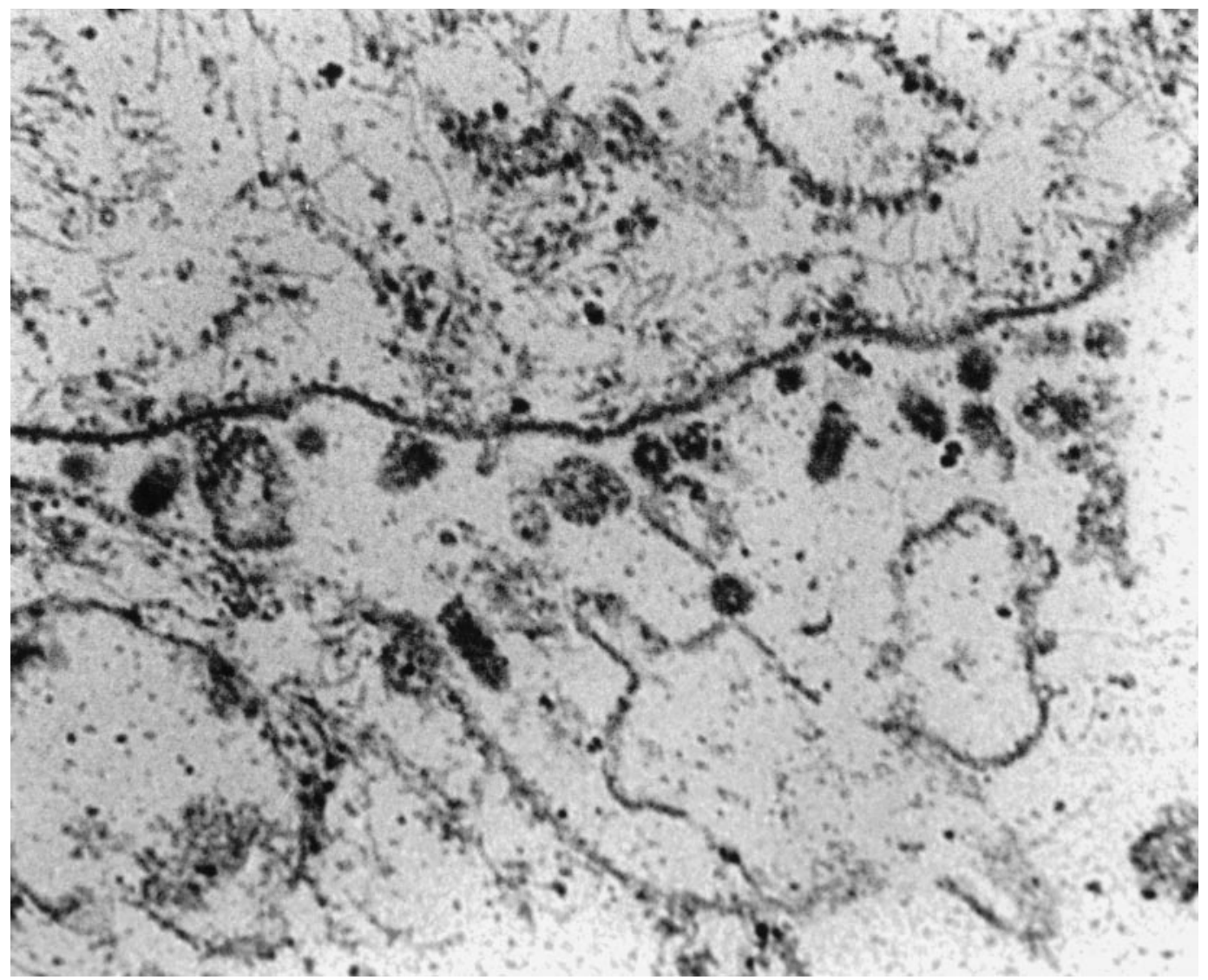

Fig. 4. Transmission electron photomicrograph of the 91-97 virus isolate after culture in snakehead spleen cells (SHS) for $72 \mathrm{~h}$ and stained with uranyl acetate and lead citrate $(\times 77000)$

the virus. Growth in the CHSE-214 cells, however, was very minimal, while AS, EPC and RTG-2 were refractory to the test virus. Thus, the actual rate of virus maturation and release from infected cells was dependent on the type of cell line used.

The virus replicated rapidly in SHS cells. Incubation time from infection to initial assembly and release from cells was as fast as 4 and 8 h, respectively, which indicates a typical viral release pattern. This pattern is similar to that reported with the SHRV rhabdovirus isolated from EUS-affected fish in Thailand (Kasornchandra et al. 1991).

Optimum growth produced viral titers of $10^{5}$ to $10^{7} \mathrm{TCID}_{50} \mathrm{ml}^{-1}$ over a wide temperature range of 15 to $30^{\circ} \mathrm{C}$. While replication was most rapid at 25 and $30^{\circ} \mathrm{C}$, the highest titer of $2.13 \times 10^{7} \mathrm{TCID}_{50} \mathrm{ml}^{-1}$ was achieved at $15^{\circ} \mathrm{C}$. The same observations were reported for UDRV (Frerichs et al. 1989). The replication temperature requirements corresponded with the water temperature ranges below $25^{\circ} \mathrm{C}$ occurring during the EUS outbreaks. In addition, the virus tolerated incubation at $37^{\circ} \mathrm{C}$ for $5 \mathrm{~d}$ but was inactivated by Day 6 . These observations indicate that the 91-97 virus propagates well at 15 to $30^{\circ} \mathrm{C}$. However, 'viability' of the virus may be compromised at $30^{\circ} \mathrm{C}$ since the released virus is inactivated within $3 \mathrm{~d}$ in a cell-free medium at this temperature. Under natural conditions, the virus is thus likely to be quickly inactivated in the aquatic environment when exposed to temperatures above $30^{\circ} \mathrm{C}$.

In developing countries such as the Philippines, where electrical shut downs are not uncommon, optimum storage temperature of the virus must be determined. The results showed the limitations of virus storage in the absence of an ultralow temperature freezer. Storage of the virus at higher temperatures of -10 and $8^{\circ} \mathrm{C}$ should not exceed 30 and $10 \mathrm{~d}$, respectively. These data also serve as a useful guide to temperatures needed during sampling and transport of the virus.

A birnavirus (Hedrick et al. 1986), several rhabdoviruses (Frerichs et al. 1989, Kasornchandra et al. 1991, Lilley \& Frerichs 1994) and a reovirus (Roberts et al. 1994) have previously been isolated from EUS-affected fishes in Thailand, Myanmar and Sri Lanka. The birnavirus and the reovirus isolations were reported only 
once, whereas rhabdoviruses have been isolated several times from EUS-affected fish. Hence, the association of rhabdoviruses with the etiology of EUS requires further study.

Morphologically, both the UDRV and the 91-97 virus have typical bullet-shapes with blunt bases and rounded opposite ends while SHRV is bacilliform with both ends rounded.

Differences in susceptibility of various cell lines to 91-97, UDRV and SHRV were noted. Atlantic salmon cells were refractory to infection with the present isolate while UDRV replicated to high titers in it (Frerichs et al. 1989). CHSE-214 cells were refractory to UDRV while low titers of the present isolate $\left(10^{3} \mathrm{TCID}_{50} \mathrm{ml}^{-1}\right)$ were produced in CHSE-214 cells. Moreover, EPC cells were refractory to both the present isolate and UDRV, while SHRV replicated optimally in them (Frerichs et al. 1989, Kasornchandra et al. 1991).

Serological tests showed the UDRV antiserum crossreacted slightly with the 91-97 virus but not with SHRV. This indicates that the 91-97 virus isolate is antigenically distinct from SHRV but somewhat related to UDRV. The very slight cross-reaction of the 91-97 virus antiserum with IHNV is considered insignificant since the IHN antiserum did not cross-react with the test virus. Other workers have also shown the serological unrelatedness of UDRV, SHRV and IHNV (Kasornchandra et al. 1992).

By and large, the foregoing morphological, growth, biochemical and cytopathological characteristics of the 91-97 virus and the antigenic relationships obtained from the present study indicate similarities and dissimilarities with the UDRV. Further studies, however, are required to determine the degree of the relationship.

Infection experiments failed to induce pathologic effects in healthy snakeheads. Frerichs et al. (1993) reported similar observations using snakehead fish rhabdovirus and the snakehead cell line retrovirus isolated from EUS fish in Thailand by IP injection and by bath. However, virus was recovered from fish visceral organs until Day 8 post-inoculation for IP injected virus and Day 5 for other test routes of the virus, indicating that the virus remained viable in the inoculated fish, having been constantly recovered predominantly from the gonad and kidney and occasionally from the liver, spleen and gill suggesting its predilection to these organs.

In view of the results obtained with the challenged fish, further studies are needed to determine the role, if any, of the virus in the pathogenesis of EUS. There is a possibility that the isolate used in the challenge studies was partially attenuated because it had been passaged quite often in tissue culture before being used for the challenges. We intend, therefore, to investigate freshly isolated strains of the virus for their connection with EUS as soon as they become available. While we do not think it likely that a rhabdovirus would account for the clinical signs associated with EUS, we consider it possible that a rhabdovirus may be the primary agent involved in predisposing fish to other organisms that may be the actual causes of EUS-type lesions.

Acknowledgements. Research funding was provided by the Aquaculture Department, Southeast Asian Fisheries Development Center and the International Development Research Centre (IDRC) of Canada (Fish Microbiology Project 3-P-881053-02). Appreciation is also due to Dr R. P. Hedrick for the CCO cells, Drs G. N. Frerichs, J. L. Fryer and J. Kasornchandra for the antisera and virus, and Dr H. M. Engelking for the detailed protocol on virus purification. Finally, the authors thank Drs J. Webster and J. A. Plumb for their critical comments and especially Dr T. P. T. Evelyn for his painstaking review of and suggestions for the revision of the manuscript.

\section{LITERATURE CITED}

Bowser PR, Plumb JA (1980) Fish cell lines: establishment of a cell line from ovaries of channel catfish. In Vitro 16:365-368

Burke JA, Mulcahy D (1980) Plaquing procedure for infectious hematopoietic necrosis virus. Appl Environ Microbiol 39:872-876

Callinan RB, Paclibare JO, Reantaso MB, Lumanlan-Mayo SC, Fraser GC, Sammut J (1995) EUS outbreaks in estuarine fish in Australia and the Philippines: associations with acid sulphate soils, rainfall, and Aphanomyces. In: Shariff M, Arthur JR, Subasinghe RP (eds) Diseases in Asian aquaculture II. Fish Health Section. Asian Fisheries Society, Manila, p 291-298

Chong SY, Ngoh GH, Chew Lim M (1990) Study of three tissue culture viral isolates from marine foodfish. Singapore J Prim Ind 18:54-57

Engelking HM, Leong JC (1989) Glycoprotein from infectious hematopoietic necrosis virus (IHNV) induces protective immunity against five IHNV types. J Aquat Anim Health $1: 291-300$

Feldman H, Wang S (1961) Sensitivity of various viruses to chloroform. Proc Soc Exp Biol Med 106:736-738

Fijan N, Sulimanovic D, Bearzotti M, Muzinic D, Zwillenberg LO, Chilmonczyk S, Vautherot JF, de Kinkelin P (1983) Some properties of the Epithelioma papulosum cyprini (EPC) cell line from carp Cyprinus carpio. Ann Virol (Inst Pasteur) 134E:207-220

Frerichs GN, Millar SD, Roberts RJ (1986) Ulcerative rhabdovirus in fish in South-East Asia. Nature 322(6076):216

Frerichs GN, Hill BJ, Way K (1989) Ulcerative disease rhabdovirus; cell line susceptibility and serological comparison with other fish rhabdoviruses. J Fish Dis 12:51-56

Frerichs GN, Millar SD, Chinabut S (1993) Clinical response of snakeheads (Ophicephalus striatus) to experimental infection with snakehead fish rhabdovirus and snakehead cell line retrovirus. Aquaculture 116:297-301

Hedrick RP, Eaton WD, Fryer JL, Groberg WG, Boonyaratpalin S (1986) Characteristics of a birnavirus isolated from cultured sand goby Oxyeleotris marmoratus. Dis Aquat Org 1:219-225

Kasornchandra J, Lannan CN, Rohovec JS, Fryer JL (1991) Characterization of a rhabdovirus isolated from the snakehead fishes (Ophicephalus striatus). In: Fryer JL (ed) Proceedings from the Second International Symposium of Viruses of Lower Vertebrates. Oregon State University 
Press, Corvallis, Oregon, p 175-182

Kasornchandra J, Engelking HM, Lannan CN, Rohovec JS, Fryer JL (1992) Characteristics of three rhabdovirus from snakehead fish Ophicephalus striatus. Dis Aquat Org 13: 89-94

Lilley JH, Frerichs GN (1994) Comparison of rhabdoviruses associated with epizootic ulcerative syndrome (EUS) with respect to their structural proteins, cytopathology and serology. J Fish Dis 17:513-522

Lilley JH, Roberts RJ (1997) Pathogenicity and culture studies comparing the Aphanomyces involved in the epizootic ulcerative syndrome (EUS) with other similar fungi. J Fish Dis 20:135-144

Lio-Po GD, Albright LJ, Alapide-Tendencia EV (1992) Aeromonas hydrophila in the epizootic ulcerative syndrome (EUS) of snakehead, Ophicephalus striatus and catfish, Clarias batrachus: quantitative estimation in natural infection and experimental induction of dermo-muscular necrotic lesion. In: Shariff M, Subasinghe RP, Arthur JR (eds) Diseases in Asian aquaculture I. Fish Health Section. Asian Fisheries Society, Manila, p 461-474

Lio-Po GD, Albright LJ, Leaño EM (1996) Experiments on virulence dose and portals of entry of Aeromonas hydrophila in the walking catfish (Clarias batrachus). J Aquat Anim Health 8:340-343

Lio-Po GD, Albright LJ, Michel C, Leaño EM (1998) Experi-

Editorial responsibility: Jo-Ann Leong,

Corvallis, Oregon, USA mental induction of lesions in snakeheads (Ophicephalus striatus) and catfish (Clarias batrachus) with Aeromonas hydrophila, Aquaspirillum sp., Pseudomonas sp. and Streptococcus sp. J Appl Ichthyol 14:75-79

Lio-Po GD, Traxler GS, Albright LJ (1999) Establishment of cell lines from catfish (Clarias batrachus) and snakeheads (Ophicephalus striatus). Asian Fish Sci 12:345-349

Roberts RJ, Willoughby LG, Chinabut S (1993) Mycotic aspects of epizootic ulcerative syndrome (EUS) of Asian fishes. J Fish Dis 16:169-183

Roberts RJ, Frerichs GN, Tonguthai K, Chinabut S (1994) Epizootic ulcerative syndrome of farmed and wild fishes. In: Muir JF, Roberts RJ (eds) Recent advances in aquaculture, Vol 5. Blackwell Science, Oxford, p 207-239

Rovozzo GC, Burke CN (1973) A manual of basic virological techniques. Prentice-Hall, Englewood Cliffs

Tonguthai K (1985) A preliminary account of ulcerative fish diseases in the Indo-Pacific region. Department of Fisheries, Ministry of Agriculture and Cooperatives, Bangkok

Wolf K, Quimby MC (1966) Lymphocystis virus: isolation and propagation in centrarchid fish cell lines. Science 151: 1004-1005

Wunner WH (1985) Growth, purification and titration of rhabdoviruses. In: Mahy BWJ (ed) Virology: a practical approach. IRL Press, Oxford, p 79-93

Submitted: December 24, 1998; Accepted: September 28, 2000 Proofs received from author(s): December 7, 2000 